\title{
The Business Case for Corporate Social Responsibility: A Review of Concepts, Research and Practice
}

\author{
Archie B. Carroll and Kareem M. Shabana ${ }^{1}$ \\ Director, Nonprofit Management \& Community Service Program \& Robert W. Scherer Professor Emeritus, \\ Department of Management, Terry College of Business, University of Georgia, Athens, GA 30602, USA, and \\ ${ }^{1}$ Assistant Professor of Management, School of Business, Indiana University Kokomo, 2300 S. Washington Street, \\ Kokomo, IN 46904, USA \\ Email: acarroll@uga.edu; kshabana@iuk.edu
}

\begin{abstract}
In this review, the primary subject is the 'business case' for corporate social responsibility (CSR). The business case refers to the underlying arguments or rationales supporting or documenting why the business community should accept and advance the CSR 'cause'. The business case is concerned with the primary question: What do the business community and organizations get out of CSR? That is, how do they benefit tangibly from engaging in CSR policies, activities and practices? The business case refers to the bottom-line financial and other reasons for businesses pursuing CSR strategies and policies. In developing this business case, the paper first provides some historical background and perspective. In addition, it provides a brief discussion of the evolving understandings of CSR and some of the long-established, traditional arguments that have been made both for and against the idea of business assuming any responsibility to society beyond profit-seeking and maximizing its own financial wellbeing. Finally, the paper addresses the business case in more detail. The goal is to describe and summarize what the business case means and to review some of the concepts, research and practice that have come to characterize this developing idea.
\end{abstract}

Over the decades, the concept of corporate social responsibility (CSR) has continued to grow in importance and significance. It has been the subject of considerable debate, commentary, theory building and research. In spite of the ongoing deliberations as to what it means and what it embraces, it has developed and evolved in both academic as well as practitioner communities worldwide. The idea that business enterprises have some responsibilities to society beyond that of making profits for the shareholders has been around for centuries. For all practical purposes, however, it is largely a postWorld War II phenomenon and actually did not surge in importance until the 1960s and beyond. Therefore, it is largely a product of the past half century.
Today, one cannot pick up a newspaper, magazine or journal without encountering some discussion of the issue, some recent or innovative example of what business is thinking or doing about CSR, or some new conference that is being held. Specific journals, news magazines, books, dictionaries, encyclopedias, websites, discussion lists and blogs treat the concept on a regular basis. The business community has formed its own organizations specializing in the topic. Business for Social Responsibility (BSR), for example, is a business association founded in 1992 to provide corporations with expertise on the subject and an opportunity for business executives to advance the field and learn from one another. There has been an explosion of interest in CSR in the European Union and around the world. The London-based 
Ethical Corporation is another organization that stages high-profile conferences addressing CSR, business ethics and sustainability concerns. Ethical Corporation is an independent media firm, launched in 2001, to encourage debate and discussion on responsible business practices. So, while CSR was once regarded as largely a domestic business issue in leading countries of origin, in recent years its popularity has spread onto the world scene, and we now see CSR initiatives in virtually all the developed nations, and initial thinking and developing taking place in emerging nations as well.

The term 'corporate social responsibility' is still in popular use, even though competing, complementary and overlapping concepts such as corporate citizenship, business ethics, stakeholder management and sustainability are all vying to become the most accepted and widespread descriptor of the field. At the same time, the concept of corporate social performance (CSP) has become an established umbrella term which embraces both the descriptive and normative aspects of the field, as well as placing an emphasis on all that firms are achieving or accomplishing in the realm of social responsibility policies, practices and results. In the final analysis, however, all these concepts are related, in that they are integrated by key, underlying themes such as value, balance and accountability (Schwartz and Carroll 2008), and CSR remains a dominant, if not exclusive, term in the academic literature and in business practice. Just to illustrate how the concept is always evolving, CSR International, a non-profit organization, announced in 2009 the birth celebration of CSR International, an exciting new organization supporting the transition from what it called the 'old CSR' (Corporate Social Responsibility) or CSR 1.0 to the 'new CSR' (Corporate Sustainability \& Responsibility) or CSR 2.0. Whether CSR 2.0 turns out to be substantially different remains to be seen.

In this review commentary, the primary subject is the 'business case' for CSR. In short, this refers to the arguments or rationales supporting or documenting why the business community should accept and advance the CSR 'cause'. The business case is concerned with the primary question: What do the business community and organizations get out of CSR; that is, how do they benefit tangibly from engaging in CSR policies, activities and practices? For most, the business case refers to the bottom-line reasons for businesses pursuing CSR strategies and policies. In developing this business case, we first provide some historical background and perspective. In addition, we provide a brief discussion of the evolving understandings of CSR and some of the long-established, traditional arguments that have been made both for and against the idea of business assuming any responsibility beyond profit-seeking and maximizing its own financial well-being. Then we address the business case in more detail. Our goal will be to describe and summarize what the business case means and to review some of the literature and practice that has come to characterize this developing concept.

\section{Background and historical perspectives}

The roots of CSR certainly extend before World War II, but we will not go back that far. It should be noted, however, that Dean Donald K. David's comments to the incoming MBA class at the Harvard Business School in 1946 are especially appropriate to recall. Dean David exhorted the future business executives to take heed of the responsibilities that had come to rest on the shoulders of business leaders (Spector 2008). In this connection, Bert Spector has argued that the roots of the current social responsibility movement can be traced to the period 1945-1960, the early years of the Cold War. He has argued that Dean David and other advocates of expanded notions of CSR used this as a means of aligning business interests with the defense of free-market capitalism against what was then perceived to be the danger of Soviet Communism (Spector 2008).

In the 1950s, there was some limited discourse about CSR. Frank Abrams, a former executive with Standard Oil Company, New Jersey, introduced concerns about management's broader responsibilities in a complex world (Abrams 1951). Abrams argued that, as management was professionalizing, companies had to think not just about profits but also about their employees, customers and the public at large. And Howard R. Bowen published his seminal book, Social Responsibilities of the Businessman in 1953 (Bowen 1953). Bowen's book was noticeably ahead of its time, by at least a decade, but it came to shape significantly future thought on the subject. William C. Frederick, a noted contributor to the CSR literature, argued that there were three core ideas about CSR that stood out in the 1950s. These included the idea of the manager as public trustee, the balancing of competing claims to corporate resources, and corporate philanthropy - business support of good 
causes (Frederick 2006). During the 1950s, there was scant discussion of linking CSR with benefits for businesses themselves. The primary focus was on businesses' responsibilities to society and doing good works for society. Theodore Levitt closed out the 1950s by warning the business world about the dangers of social responsibility (Levitt 1958). In spite of Levitt's warnings, CSR would grow in popularity and take shape during the 1960s, driven largely by the social movements that defined the times, especially in the US, and by the forward-thinking academics who were attempting to articulate what CSR really meant and implied for business.

In the US, the most important social movements of the 1960s included civil rights, women's rights, consumers' rights and the environmental movement. Key events, people and ideas in these movements were instrumental in characterizing the social changes ushered in during the 1960s. In each of these arenas, business perceived expectations being communicated which eventually had to be addressed. Thus, the foundation for CSR was being developed by a quickly changing social environment and pressures from others, especially activists, to adopt CSR perspectives, attitudes, practices and policies. In the 1960s, companies initially did not perceive a 'social' environment in the way that we do today. Yet, piece by piece, the overall social environment was being constructed by these movements, and the result would be a dramatically different context, in which business would then have to operate. Though the 1960s seemed ripe for advances in social responsibility thought, the decade was still reeling from Professor Theodore Levitt's admonitions about 'the dangers of social responsibility'. Levitt thought that social concerns and the general welfare were not the responsibility of business, but of government, and that business's job was to 'take care of the more material aspects of welfare'. Levitt feared that attention to social responsibilities would detract from the profit motive that was so essential for business success. But, there were also positive voices advocating the social responsibility movement. In fact, significant progress was made by both government and academics, and businesses were following in parallel.

As the 1960s transitioned into the 1970s and beyond, the particular emphasis in the CSR concept evolved primarily through the academic contributions in the literature and the slowly emerging realities of business practice. This history and evolution has been treated elsewhere (Carroll 1999, 2008; Lee
2008), so only some thematic highlights are touched upon here. The CSR literature expanded significantly during the 1960s, and it tended to focus on the question of what social responsibility actually meant and its importance to business and society. Keith Davis argued that social responsibility referred to 'businessmen's decisions and actions taken for reasons at least partially beyond the firm's direct economic or technical interest' (Davis 1960, p. 70). At the same time, William C. Frederick argued that businesses' resources should also be used for broad social goals (Frederick 1960, p. 60), and Joseph McGuire posited that social responsibility urges corporations to assume certain responsibilities to society which extend beyond their economic and legal obligations (McGuire 1963). A later analysis by Patrick Murphy argued that the 1960s and early 1970s were the 'Awareness' and 'Issue' eras of CSR. This was a period of changing social consciousness and recognition of overall responsibility, involvement in community affairs, concern about urban decay, correction of racial discrimination, alleviation of pollution, and the continuing philanthropic era in which there was a focus on charitable donations by businesses (Murphy 1978). From about the 1950s forward, Hay and Gray characterized this period of CSR development as 'Quality of Life Management', as contrasted with earlier periods, which emphasized profit maximization and trusteeship management (Hay and Gray 1974). Frederick characterized the 1960 s and 1970s as a stage of 'corporate social responsiveness' (Frederick 2008). Another characteristic of the 1960s was an absence of any coupling of social responsibility with financial performance (Lee 2008 , p. 58). In other words, social responsibility was driven primarily by external, socially conscious motivations, and businesses were not looking for anything specific in return.

Formal definitions of CSR began to proliferate in the 1970s, and the overall trajectory was towards an emphasis on CSP (Carroll 1999; Sethi 1975). The 1970s was the decade in which corporate social responsibility, responsiveness and performance became the center of discussions. Ackerman (1973) and Murray (1976) argued that what was really important was not that companies were 'assuming a responsibility', but that companies were responding to the social environment. Frederick (1978) formalized this distinction by differentiating corporate social responsibility $\left(\mathrm{CSR}_{1}\right)$ from corporate social responsiveness $\left(\mathrm{CSR}_{2}\right)$. $\mathrm{CSR}_{1}$ emphasized companies 'assuming' a socially responsible posture, 
whereas $\mathrm{CSR}_{2}$ focused on the literal act of responding or of achieving a responsive posture towards society. In the mid-1970s, an emphasis on CSP more clearly emerged. In one respect, CSP was an attempt to reconcile the importance of both $\mathrm{CSR}_{1}$ and $\mathrm{CSR}_{2}$, but it was also about placing an emphasis on achieving results or emphasizing the outcomes of socially responsible initiatives (Carroll 1979; Wartick and Cochran 1985; Wood 1991). This focus on outcomes was moving the field closer to the idea of the 'business case'. At least when outcomes are emphasized, this sets the stage for attempts to measure or gauge the results of CSR policies and practices.

On the CSR front, the 1980s produced fewer new definitions of the concept, more empirical research, and the rise and popularity of alternative themes. These CSR variants included corporate public policy, business ethics and stakeholder theory/ management as well as further developments in CSP which arrived on the scene in the 1970s (Carroll 1999, pp. 285-289). Frederick termed the 1980s as the beginning of the 'corporate/business ethics' stage, wherein the focus became fostering ethical corporate cultures (Frederick 2008). Research seeking to link CSR with corporate financial performance (CFP) exploded during this decade, and the search for a tighter coupling with firm financial performance became the order of the day (Lee 2008, p. 58). One could well argue that the search for the business case for CSR began and came-of-age during this decade, especially for academic researchers. This trend continued in the 1990s, and the quest for CSR accelerated in terms of its global outreach. The 1990s and 2000s became the era of global corporate citizenship (Frederick 2008). The early 2000s became preoccupied with the Enron Era of scandals, and these headlined the news until 2008, when the Wall Street Financial Scandals Era began wreaking havoc all over the globe and will most likely be with us for some time (Carroll 2009). Though CSR continued its quest to find business legitimacy, the emergence and preoccupation with business ethics obscured the continued growth and development of the social responsibility theme, though significant advances were made, especially in the UK and continental Europe (Moon 2005). The quest for the business case for CSR certainly became a dominant theme during this period, especially as the business community was seeking to rationalize and legitimize the activities it had begun and were continuing. In the early 2000 s, the business community became fascinated with the notion of sustainability, or sustainable development, and this theme became an integral part of all CSR discussions.

\section{Arguments for and against CSR}

Ever since the debate over CSR began, supporters and detractors have been articulating the arguments for the idea of CSR and the arguments against the concept of CSR. These arguments have been discussed extensively elsewhere, but a brief recapitulation of them makes sense as we lead up to presenting the 'business case'. Embedded in the arguments both for and against CSR are points which have been made previously, perhaps on a piecemeal basis, supporting the business case.

The case against the concept of CSR typically begins with the classical economic argument articulated most forcefully by the late Milton Friedman (1962). Friedman held that management has one responsibility and that is to maximize the profits of its owners or shareholders. Friedman argued that social issues are not the concern of business people and that these problems should be resolved by the unfettered workings of the free market system. Further, this view holds that, if the free market cannot solve the social problems, it falls not upon business, but upon government and legislation to do the job. A second objection to CSR has been that business is not equipped to handle social activities. This position holds that managers are oriented towards finance and operations and do not have the necessary expertise (social skills), to make socially oriented decisions (Davis 1973). A third objection to CSR is that it dilutes businesses' primary purpose. The objection here is that to adopt CSR would put business into fields of endeavor that are unrelated to their 'proper aim' (Hayek 1969). A fourth argument against CSR is that business already has enough power, and so why should we place in its hands the opportunity to wield additional power, such as social power (Davis 1973)? A fifth argument is that, by pursuing CSR, business will make itself less competitive globally. It should be noted that the arguments presented here were introduced decades ago, though some still hold them, and that the oppositions to the concept of CSR applied when the idea was once more narrowly conceived.

Arguments in favor of CSR typically begin with the belief that it is in business's long-term selfinterest - enlightened self-interest - to be socially 
responsible. This view holds that, if business is to have a healthy climate in which to function in the future, it must take actions now that will ensure its long-term viability. A second argument in favor of CSR is that it will 'ward off government regulation'. This is a very practical reason, and it is based on the idea that future government intervention can be forestalled to the extent that business polices itself with self-disciplined standards and fulfills society's expectations of it. Two additional arguments in favor of CSR include 'business has the resources' and 'let business try'. These two views maintain that, because business has a reservoir of management talent, functional expertise and capital, and because so many others have tried and failed to solve social problems, business should be given the chance (Davis 1973, p. 316). Another justification for CSR holds that proacting is better than reacting. This basically means that proacting (anticipating, planning and initiating) is more practical and less costly than simply reacting to social problems once they have surfaced (Carroll and Buchholtz 2009). Finally, it has been argued that business should engage in CSR because the public strongly supports it. Today, the public believes that, in addition to its pursuits of profits, business should be responsible to their workers, communities and other stakeholders, even if making things better for them requires companies to sacrifice some profits (Bernstein 2000). Many of these arguments for and against CSR have been around for decades. They certainly present the legitimate perspective that there are, indeed, two sides of the argument with respect to almost any concept.

\section{Defining CSR for business case purposes}

Over the past half century, many different definitions of what CSR really means have been set out. One recent study identified 37 definitions of CSR (Dahlsrud 2006), and this figure underestimates the true number, because many academically derived definitional constructs were not included owing to the methodology for identifying them. Most of the academically derived definitional constructs have been discussed elsewhere (Carroll 1999), so we will touch upon only a few of them here to illustrate the evolving nature of CSR's meaning. What is particularly noteworthy of recent accounts of CSR definitions is how many of them have been introduced by various practitioner and quasi-practitioner groups. A recent
Google search of CSR definitions, for example, revealed that the definitions most often found in articles and web pages have been set out by organizations such as BSR, the Commission of the European Communities and CSRwire (Dahlsrud 2006). There are many different ways to think about what CSR includes and what all it embraces. A recent study found that definitions tended to identify various dimensions that characterized their meaning. Using content analysis, this study identified five dimensions of CSR and used frequency counts via a Google search to calculate the relative usage of each dimension. The study found the following to be the most frequent dimensions of CSR: stakeholder dimension, social dimension, economic dimension, voluntariness dimension and environmental dimension (Dahlsrud 2006). Though these dimensions were identified via Google citations, no research attesting to their validity has been done.

Another way to think about CSR is to identify the different categories of CSR and sort out companies' activities in terms of these different types, classes or kinds of CSR. Using this approach, we decided to employ Carroll's four different categories of CSR, which include businesses' fulfillment of economic, legal, ethical and discretionary/philanthropic responsibilities. This four-part definition of CSR has been stated as follows: 'The social responsibility of business encompasses the economic, legal, ethical, and discretionary [later referred to as philanthropic] expectations that society has of organizations at a given point in time' (Carroll 1979, p. 500, 1991, p. 283). Because this definition has been used successfully for research purposes for over 25 years, it was decided this might be a positive and appropriate definition to use because of its enduring application in CSR research.

Another reason why this definition is useful is that it specifies the firm's economic responsibility as a factor to be considered in CSR, and this becomes very important in thinking about the 'business case'. Business people, in particular, like to think of their economic/financial/profitability performance as something that they are doing not only for themselves, but also for society, as they fulfill their institutions' mission to provide goods and services for society. Further, the definition separates out legal, ethical and philanthropic categories of responsibility/performance, and this provides for a sharper examination of different corporate actions. Further, the four categories of responsibility/ performance embrace the five dimensions of CSR 
discussed earlier. Whether in the definition's structure or its application, business performance with respect to the environment, stakeholders and society (social) are captured along with the categories of economics and voluntariness (discretionary/ philanthropic). The four categories of CSR - economic, legal, ethical and philanthropic - address the motivations for initiatives in the category and are also useful in identifying specific kinds of benefits that flow back to companies, as well as society, in their fulfillment. Of course, these concepts can be overlapping and interrelated in their interpretation and application, but they are helpful for sorting out the specific types of benefits that businesses receive, and this is critical in building the 'business case'.

\section{The essence of CSR: ethical and philanthropic responsibilities}

Carroll's (1979, 1991) four-part definition of CSR identifies four categories of responsibilities: economic, legal, ethical and discretionary/philanthropic. These 'responsibilities' are the expectations placed on the corporation by corporate stakeholders and society as a whole. One of the major advantages of Carroll's definition is its expansion of the categories of CSR that McGuire referred to in 1963. McGuire (1963, p. 144) argued: 'The idea of social responsibilities supposes that the corporation has not only economic and legal obligations, but also certain responsibilities to society which extend beyond these obligations.' By identifying and distinguishing the ethical and discretionary/philanthropic categories, Carroll explicitly spelled out what McGuire referred to as the responsibilities that extend beyond the economic and legal responsibilities. Carroll then made the notion of CSR more explicit when he contended that the economic and legal responsibilities are 'required', the ethical responsibilities are 'expected', and the discretionary/philanthropic responsibilities are 'desired'. By doing so, he made a distinction between the traditional and the new responsibilities of the corporation. The classical responsibilities of the corporation which are embodied in its economic and legal responsibilities reflect the old social contract between business and society. Alternatively, the new responsibilities of the corporation which are embodied in the ethical and discretionary/philanthropic responsibilities reflect the new, broader, social contract between business and society.

Since what is debated in the subject of CSR are the nature and extent of corporate obligations that extend beyond the economic and legal responsibilities of the firm, it may be understood that the essence of CSR and what it really refers to are the ethical and philanthropic obligations of the corporation towards society. Kotler and Lee (2005) essentially see CSR in the same way. They define CSR as 'a commitment to improve community well-being through discretionary business practices and contributions of corporate resources'.

\section{Remarks on the economic and legal responsibilities of business}

Economic responsibilities. The economic responsibility of business is 'to produce goods and services that society desires and to sell them at a profit' (Carroll 1979, p. 500). By doing so, businesses fulfill their primary responsibility as economic units in society. The critical question is: To what extent should a business pursue profits? Carroll (1991, p. 41) observes that the profit principle was originally set in terms of 'acceptable profits'; however, the principle transformed to 'profit maximization'. The doctrine of profit maximization is endorsed by the classical economic view led by the late Milton Friedman (1962) where 'there is one and only one social responsibility of business - to use it resources and engage in activities designed to increase its profits so long as it stays within the rules of the game, which is to say, engages in open and free competition without deception or fraud'. Drucker (1954/2006) presents an alternative perspective to the classical economic view. He argues that profit performs three main functions. First, it measures the effectiveness of business activities; second, it provides a 'risk premium' necessary for the corporation to stay in business; and third, it insures the future supply of capital. 'A profitability objective therefore measures not the maximum profits the business can produce, but the minimum it must produce' (Drucker 1954/2006, pp. 76-77).

It is worth noting that Barnett (2007) provides an argument which seems to indicate that the principle of maximizing shareholder wealth is, in itself, not in the interest of shareholders. Barnett contends that excessive financial performance leads to decreasing the ability of the company to influence its stakeholders. Barnett (2007, p. 808) explains:

Doing too well can lead stakeholders to perceive that a firm is not doing enough good. Excessive CFP indicates that a firm is extracting more from society than it is returning and can suggest that 
profits have risen because the firm has exploited some of its stakeholders in order to favor shareholders and upper management. This can indicate untrustworthiness to stakeholders looking to establish or maintain relations with the firm.

While tension remains between these two views of profit, the notion of an economic responsibility in terms of financial profit to stockholders is accepted and required by both views. One may even argue that maximizing shareholder wealth in the long run is an underlying principle of both views. The real difference may be that the classical economic view fails to appreciate the long-term negative effects of the application of the maximization principle in the short term. In contrast, the opposite view applies the maximization principle for long-term benefits, which entails that such principle may be suppressed in certain short-term considerations.

Legal responsibilities. The legal responsibilities of business refer to the positive and negative obligations put on businesses by the laws and regulations of the society where it operates. Little disagreement exists between the various views on CSR regarding what constitutes the legal responsibilities of business. All views accept the requirement of adherence to the laws and regulations of society. The difference really exists regarding the nature and scope of such an obligation. With respect to the nature of the legal obligations, on the one hand, some views contend that the legal responsibility of business constitutes the totality of the responsibility of business towards society. On the other hand, some argue that laws and regulations constitute but one category of the responsibility of business towards society. For example, Carroll (1991, p. 41) considers the laws and regulations as the 'codified ethics' of society. They represent "partial fulfillment of the social contract between business and society'.

With respect to the scope of the legal responsibilities, some advocate its expansion to encompass more regulation. They claim that regulation is necessary for the fulfillment of CSR. For example, De Schutter (2008, p. 203) argues that the business case for CSR 'rests on certain presuppositions about markets and the business environment, which cannot be simply assumed, but should be affirmatively created by a regulatory framework for CSR'. Others oppose such claims and assert that engagement in CSR activities and management of stakeholder relations should continue to remain voluntary. For example, Phillips et al. (2003) reject the claim that stakeholder theory, which contends that firm performance is influenced by the firm's management of its relationships with its stakeholders, promotes expanding or changing laws and regulations. The authors assert that stakeholder theory 'does not require a change in the law to remain viable' (Phillips et al. 2003, p. 491).

The two opposing camps continue to present their arguments to justify the need for the expansion or contraction of the legal requirements imposed on business. Advocates of regulation question the ability of the free market mechanism to support CSR activities (e.g. Valor 2008; Williamson et al. 2006). They contend that market failure and the business environment are not rewarding firms engaging in CSR activities. In contrast, opponents of regulation argue that the free market mechanism promotes the interest of individuals, and in turn society, by rewarding CSR activities that are actually favored by individuals. Corporate social responsibility activities that are not rewarded by the market are those activities that individuals do not value and are therefore unwilling to support. The merit of CSR activities, thus, should be determined by the free market mechanism.

\section{The business case for CSR: What does it really mean?}

Before presenting a review and summary of the 'business case' for social responsibility, it is important to discuss what this really means. When one examines the history and evolution of CSR, the idea of a business case for CSR has been developing almost since the beginning. Even with early CSR initiatives, there was always the built-in premise that, by engaging in CSR activities, businesses would be enhancing the societal environment in which they existed and that such efforts would be in their longterm enlightened self-interest. Though CSR came about because of concerns about businesses' detrimental impacts on society (avoiding 'negatives'), the theme of improving society (creating 'positives') was certainly in the minds of early theorists and practitioners. With the passage of time and the growth of resources being dedicated to social responsibility, it was only natural that questions would begin to be raised about whether CSR was paying its own way, so to speak. Another incentive for the development of the business case was probably a response to Milton Friedman's continuing arguments against the concept, claiming that businesses must focus only on long-term profits. If it could be demonstrated that 
businesses actually benefited financially from CSR, then possibly Friedman's arguments would somewhat be neutralized.

In essence, then, the quest for the business case for CSR has been developing for several decades. In recent times, the search for the 'business case' for CSR has accelerated and has come to mean the establishment of the 'business' justification and rationale, that is, the specific benefits to businesses in an economic and financial sense that would flow from CSR activities and initiatives. Questions such as the following have framed this search: Can a firm really do well by being good? Is there a return on investment to CSR? What are the bottom-line benefits of socially responsible corporate performance? Is CSP positively related to CFP? It has been argued that, in business practitioner terms, a 'business case' is 'a pitch for investment in a project or initiative that promises to yield a suitably significant return to justify the expenditure'. That is, can companies perform better financially by addressing both their core business operations and their responsibilities to the broader society (Kurucz et al. 2008)?

Who really cares whether CSR improves the bottom line? Obviously, corporate boards, CEOs, CFOs and upper echelon business executives care. They are the guardians of their companies' financial welfare and ultimately must bear responsibility for the impact of CSR on the bottom line. At various levels, they need to justify that CSR is consistent with the firm's strategies and that it is financially sustainable (O'Sullivan 2006). But, other groups care as well. Shareholders are increasingly concerned with financial performance and are concerned about possible threats to management's priorities. Social activists care because it is in their long-term best interests if companies can sustain the types of social initiatives which they are advocating. Governmental bodies care because they desire to see whether companies can deliver social and environmental benefits more cost effectively than they can through regulatory approaches (Zadek 2000). It may also be argued that average consumers care as well, as they want to pass on a better world to their children, and many want their purchasing to reflect their values.

It should also be emphasized that a multitude of different business cases for social responsibility have been developing over the years. There is no single business case for CSR - no single rationalization for how CSR improves the bottom line. Many different arguments have been assembled to justify the composite business case. The business case for CSR has been broken down into four different categories by Simon Zadek. Zadek has argued that companies pursue CSR strategies to (1) defend their reputations (pain alleviation), (2) justify benefits over costs (the 'traditional' business case), (3) integrate with their broader strategies (the 'strategic' business case), and (4) learn, innovate and manage risk (New Economy Business case) (Zadek 2000). Kurucz et al. (2008, pp. 85-92) also have set out four general types of business case for CSR which overlap with Zadek's. They maintain that there are four different groupings of the business case based on the focus of the approach, the topics addressed, and the underlying assumptions about how value is created and defined. Their four approaches include: (1) cost and risk reduction; (2) gaining competitive advantage; (3) developing reputation and legitimacy; and (4) seeking win-win outcomes through synergistic value creation. Other widely accepted approaches to the business case include focusing on the empirical research linking CSR with CSP and identifying benefits to different stakeholder groups that directly or indirectly benefit companies' bottom lines. In addition, the socially conscious investment movement, sometimes called 'ethical investing' is often built on the belief that there exists a strong correlation between social performance and financial performance. Others, by contrast, believe socially conscious investing is simply the right thing to do. It is against this backdrop that we review some of the primary arguments that have been developed constituting the composite business case.

\section{Documenting the business case for CSR}

Attention to the business case for CSR has gained noticeable consideration. Lee (2008, p. 53) observes a trend in the evolution of CSR theories that reveal 'a tighter coupling [between CSR and the] organizations' financial goals'. The focus of CSR theories has shifted away from an ethics orientation to a performance orientation. In addition, the level of analysis has moved away from a macro-social level to an organizational level, where the effects of CSR on firm financial performance are closely examined. Vogel (2005) maintains that the close examination of the relationship between CSR initiatives and firm financial performance is a characteristic of the 'new world of CSR'. He argues that 'old style' CSR of the 1960s and 1970s was motivated by social consider- 
ations. Economic considerations were not among the motives for CSR: '[w] hile there was substantial peer pressure among corporations to become more philanthropic, no one claimed that such firms were likely to be more profitable than their less generous competitors'; in contrast, the essence of the 'new world of CSR' is 'doing good to do well' (Vogel 2005, pp. 20-21).

Vogel observes some features of the "new world of CSR'. He notes that the new world of CSR emphasizes the link between CSR and corporate financial success. Evidence for such emphasis, Vogel states, are the many works (e.g. Jackson 2004; Laszlo 2003; Scott and Rothman 1992; Waddock 2002) that promote the 'responsibility-profitability connection' and assert that CSR leads to long-term shareholder value. He also reports that '[a]ccording to a 2002 survey by PricewaterhouseCoopers, "70 percent of global chief executives believe that CSR is vital to their companies' profitability"'. This evidence suggests that CSR is evolving into a core business function which is central to the firm's overall strategy and vital to its success.

\section{A broad and a narrow view of the business case for CSR}

Berger et al. (2007) examine the integration of CSR considerations in the day-to-day business agenda of organizations. They argue that the 'mainstreaming' of CSR follows from one of three rationales: the social values-led model, the business-case model and the syncretic stewardship model. In the social valuesled model, organizations adopt CSR initiatives regarding specific issues for non-economic reasons. 'CSR [is] the organization's lifeblood and [is] integrated into the organizational fiber in every way' (Berger et al. 2007, p. 141). By contrast, in both the business-case model and the syncretic stewardship model, organizations adopt CSR initiatives for 'rational' reasons. In the business-case model, CSR initiatives are assessed in a purely economic manner. They are only pursued when there is a clear link to firm financial performance. ' $[\mathrm{M}]$ ainstreaming CSR meant aggressively pursuing viable business opportunities with a CSR dimension' (Berger et al. 2007, p. 140). In the syncretic stewardship model, the firm is attuned to 'the external market for virtue' while embracing 'economic objectives' (Berger et al. 2007, p. 143). In the syncretic model, CSR is a 'management philosophy, an overarching approach to business' (Berger et al. 2007, p. 144).
The business-case model and the syncretic model proposed by Berger et al. (2007) may be seen as two views of the business case for CSR: narrow and broad. On the one hand, the business-case model represents the narrow view of the business case. In this model, the business case is narrow because CSR is only recognized when there is a clear link to firm financial performance. Often this clear link refers to direct relationships between CSR initiatives and firm performance. On the other hand, the view of the business case illustrated by the syncretic model is broad because it recognizes direct and indirect relationships between CSR and firm performance. The advantage of the broad view over the narrow one is that the broad view allows the firm to value and appreciate the complex relationship between CSR and firm performance. Such appreciation may enable the firm to identify and exploit opportunities that the narrow view would not be able to recognize.

Another advantage of the broad view of the business case, which is illustrated by the syncretic model, is its recognition of the interdependence between business and society (Berger et al. 2007). The failure to recognize such interdependence in favor of pitting business against society, Porter and Kramer (2006) argue, leads to reducing the productivity of CSR initiatives. The authors assert, 'the prevailing approaches to CSR are so fragmented and so disconnected from business and strategy as to obscure many of the greatest opportunities for companies to benefit society' (Porter and Kramer 2006, p. 80). The adoption of CSR practices, their integration with firm strategy, and their mainstreaming in the day-today business agenda should not be done in a generic manner. Rather, it should be pursued 'in the way most appropriate to each firm's strategy' (Porter and Kramer 2006, p. 78).

\section{The CSP-CFP relationship}

Perhaps the first attempt to establish the business case for CSR has been the pursuit of establishing a positive relationship between CSP and CFP. Margolis and Walsh (2003, p. 268) describe this endeavor as a '30-year quest for an empirical relationship between a corporation's social initiatives and its financial performance'. Griffin and Mahon (1997) present a review and an assessment of studies exploring the CSP-CFP relationship. The authors conclude that there is a positive relationship between CSP and CFP. They argue that inconsistencies in the results of previous empirical studies investigating the CSP-CFP 
relationship may be attributed to methodological differences. Roman et al. (1999) disagree with Griffin and Mahon and offer a different conclusion. They argue that results produced by CSP-CFP studies fall into three categories. One category shows a positive link between CSP and CFP, the second shows a negative link, and the third shows no link. The authors thus conclude that the results are inconclusive. Mahon and Griffin (1999) respond to Roman et al. (1999) by acknowledging that the CSP-CFP relationship merits further investigation; however, they contend that the findings of Roman et al. (1999) are influenced by interpretation biases. Mahon and Griffin assert:

By analyzing the facts gleaned to date, the true nature of the portrait can be highlighted, and the framing of the portrait narrowed. However, our concern is that if we blur the portrait with our preconceived notions of what it should be and how it should look, and if we inconsistently apply rules to include and exclude portions of it, we will be like the blind Indian men and we will miss many overarching themes inherent in this elephant. (Mahon and Griffin 1999, p. 131)

Margolis and Walsh seem to provide support for the Griffin and Mahon (1997) and Mahon and Griffin (1999) positions. They present a review and assessment of 127 empirical studies exploring the CSPCFP relationship, in which they conclude that a 'simple compilation of the findings suggests there is a positive association, and certainly very little evidence of a negative association, between a company's social performance and its financial performance' (Margolis and Walsh 2003, p. 277). In addition, the meta-analysis by Orlitzy et al. (2003) supports a positive relationship between CSR and CFP. Finally, it should be indicated that a recent (2008) major survey from the Economic Intelligence Unit (EIU) suggests that the vast majority of US business leaders now accept that there is a clear correlation between CSR performance and financial performance. The study showed that the managerial support for CSR initiatives extends to the corporate board level as well (BusinessGreen 2008).

On the whole, CSP-CFP research seems to indicate the existence of a positive relationship between CSP and CFP; however, some inconsistencies linger. In light of the broad view of the business case for CSR these inconsistencies may be attributed not only to methodological differences and interpretation biases, but also to the existence of mediating variables and situational contingencies that influence the
CSP-CFP relationship. Future research that accounts for these factors would indeed improve understanding of the CSP-CFP relationship and would take us a step closer to articulating conclusive findings.

\section{Beyond the CSP-CFP relationship: mediating variables and situational contingencies}

The broad view of the business case for CSR suggests that the relationship between CSR and firm financial performance is better depicted when the role of mediating variables and situational contingencies are accounted for. Such a view would allow for the realization of the full potential of CSR initiatives. An affirmative corporate social agenda may therefore be created. This affirmative agenda 'looks beyond community expectations to opportunities to achieve social and economic benefits simultaneously. It moves from mitigating harm to finding ways to reinforce corporate strategy by advancing social conditions' (Porter and Kramer 2006, p. 85).

Pivato etal. (2008) drew attention to the importance of the role of mediating variables in the responsibility-performance relationship. The authors argued that attention must be given to 'intermediate performance measures, such as customer satisfaction, ... to prove positive correlations with social investment' (Pivato et al. 2008, p. 3). In addition, the authors contend that examining specific drivers of social performance rather than its indicators would be more beneficial. Pivato et al. (2008) support their claim by an empirical study which illustrates that social performance positively influenced brand loyalty through building trust with consumers. The study indicates that CSR initiatives may have an indirect positive influence on firm financial performance. Accordingly, appreciation of the complexity of the relationship between CSR and firm financial performance would be much more beneficial than a simplistic view that only recognizes the clear and direct responsibility-performance relationship.

Barnett (2007) argues that the impact of CSR on CSP varies from one firm to the other. He explains that such variation, which is reflected by the inconclusive results from CSP-CFP research, may be attributed to factors specific to each situation. In other words, situational contingencies affect the relationship between CSR and firm financial performance. Accordingly, CSR may have a positive effect on firm financial performance in certain situations, while having negative or no effect in other situations. One of the factors that determines whether CSR has 
a positive, negative or neutral effect on firm financial performance is stakeholder influence capacity (SIC), which refers to 'the ability of a firm to identify, act on, and profit from opportunities to improve stakeholder relationships through CSR' (Barnett 2007, p. 803). The aggregate benefits accruing from a firm's past interactions with its various stakeholders form an intangible asset, which may be referred to as a firm's SIC stock. A firm's SIC stock influences the extent to which the firm is able to impact its stakeholders through future CSR practices. Higher levels of SIC stock would allow a firm to garner support from its stakeholders regarding certain CSR practices. Conversely, lower levels of SIC stock would limit a firm's ability to cultivate stakeholder support with respect to certain CSR practices. SIC stock, then, moderates the relationship between CSR and stakeholder relations (Barnett 2007).

The identification of the role of mediating variables and situational contingencies improves the understanding of the responsibility-performance relationship. Firms are therefore able to identify and pursue profitable CSR initiatives and establish a reinforcing relationship between corporate strategy and the advancement of social conditions as suggested by Porter and Kramer (2006). Consequently, the business case for CSR is made clearer and more compelling.

\section{Evidence of the business case for CSR}

As stated previously, the business case for CSR refers to the 'business' justification and rationale; that is, the specific benefits to businesses in an economic and financial ('bottom-line') sense that would flow from CSR activities and initiatives. In some cases, the effect of CSR activities on firm financial performance may be seen clearly and directly. In other cases, however, the effect of CSR activity on firm performance may only be seen through the understanding of mediating variables and situational circumstances.

In this section, we present evidence of the effect of CSR on firm performance in support of the business case. The evidence primarily illustrates the effect of CSR on firm performance through mediating variables and situational circumstances. First, the discussion highlights the prevalence of CSR activities and the range of their adoption by business. Second, the discussion reviews the benefits of CSR that flow from firms' fulfillment of their ethical and philan- thropic responsibilities, which we argued constitutes the essence of CSR. Discussion of the benefits flowing from each category of responsibility is organized according to the framework put forward by Kurucz et al. (2008, pp. 85-92), which identifies four categories of benefits that firms may attain from engaging in CSR activities: (1) cost and risk reduction; (2) gaining competitive advantage; (3) developing reputation and legitimacy; and (4) seeking win-win outcomes through synergistic value creation. Finally, we discuss some of the criticisms and limitations of the current arguments of the business case for CSR.

It may be worth reiterating at this point what aspect of CSR is especially relevant in the current discussion. As stated previously, essentially, CSR refers to the obligations of the corporation towards society which extend beyond its economic and legal obligations. These obligations are identified as the ethical and discretionary/philanthropic responsibilities. We hold that these two categories of responsibilities capture and embrace the essence of the concept of CSR, especially for building the business case. For, without a doubt, few business people would question the economic and legal responsibilities as being necessary for survival and growth.

The prevalence of CSR practices with business-case effects

Ethical responsibilities in practice. The ethical responsibilities of business 'embody those standards, norms, or expectations that reflect a concern for what consumers, employees, shareholders, and the community regard as fair, just, or in keeping with the respect or protection of stakeholders' moral rights' (Carroll 1991, p. 41). In essence, ethical responsibilities refer to a corporation's voluntary actions to promote and pursue social goals that extend beyond their legal responsibilities. These goals are of importance to society or to different stakeholders in society, but their promotion and pursuit are beyond the corporation's immediate financial interest. The importance of these social goals to society may be inferred from the presence of an interest to identify them and measure and report corporate performance regarding them.

Perhaps the most widely known and accepted measure of corporate performance regarding social goals is the Kinder, Lydenberg, Domini (KLD) social performance index. The KLD index covers corporate performance regarding environmental, social and 
governance issues. In addition, the index includes measures for controversial business issues. Environmental issues include climate change, products and services, and operations and management; social issues include community, diversity, employee relations, human rights and product; governance issues include reporting and structure; and, finally, controversial business issues include abortion, adult entertainment, alcohol, contraceptives, firearms, gambling, military, nuclear power and tobacco (KLD Research and Analytics, Inc. 2009). The Global Reporting Initiative (GRI) provides an alternative framework to assess CSP. In addition to economic and environmental indicators, its Sustainability Reporting Guidelines (Global Reporting Initiative 2006) identify four categories of social performance indicators: labor practices and decent work, human rights, society and product responsibility. Both the KLD index and the GRI sustainability reporting guidelines indicate the presence of societal and stakeholder concerns regarding corporate performance pertaining to social goals.

In response to the mounting social and stakeholder concerns, many corporations are adopting initiatives and programs directed at the ethical responsibilities of business. For example, the British paper manufacturer Antalis seeks to reduce the negative impact of its operations on the natural environment by adopting a 'green' philosophy. Antalis became 'the first UK paper merchant to be certified under both the Forest Stewardship Council (FSC) and Programme for the Endorsement of Forest Certification (PEFC)' (Printing World 2005, p. 41). In addition, Antalis supports suppliers whose operations meet or exceed the environmental standards set by international organizations which aim to improve environmental performance of business, such as the International Standards Organization and the Eco-management and Audit Scheme (Printing World 2005). The green philosophy adopted by the company is not mandated by law. Rather, it is a voluntary initiative which aims to fulfill an ethical responsibility of business.

Another example of a program directed at fulfilling the ethical responsibility of business is Starbucks' participation in the Fairtrade coffee market. Coffee is labeled Fairtrade when certified by TransFair USA, which is the US branch of Fair Trade Labeling Organizations (FLO). 'Under FLO's policies, farmers are provided credit and assured a minimum of $\$ 1.26$ per pound' (Cray 2000, p. 4). Starbucks announced that it will 'double its purchase [of Fairtrade coffee] to 40 million pounds in 2009'
(Starbucks 2009). Starbucks' participation in Fairtrade dates back to April, 2000 when it first 'signed a contract with TransFair USA to sell Fairtrade certified coffee in more than 2000 stores, beginning ...ffall [2000]' (Cray 2000, p. 4). Starbuck's program, similar to Antalis' green philosophy, is voluntary and aims to fulfil an ethical responsibility of business.

Philanthropic responsibilities in practice. The discretionary/philanthropic responsibilities of business encompass 'those corporate actions that are in response to society's expectation that business be a good corporate citizen. This includes actively engaging in acts or programs to promote human welfare or good will' (Carroll 1991, p. 42). Many businesses make donations directed at various causes such as education, community improvement, and arts and culture (Seifert et al. 2004). The Committee Encouraging Corporate Philanthropy (CECP) reports that, according to a 2007 survey, the median total giving of Fortune 100 companies was $\$ 46.31$ million, with $71 \%$ of Fortune 100 companies giving more than they did in 2006 (CECP 2009a). Bruch and Walter (2005, p. 49) observe that '[i]n the United Kingdom alone, leading publicly traded companies made donations to non-profit organizations in 2003 and 2004 that were valued at more than $\$ 1.6$ billion and that equaled close to $1 \%$ of the companies' pre-tax profits'. Corporate philanthropy is not a new phenomenon. Seifert et al. (2003, p. 195) report that 'corporate philanthropy as a percentage of profits averaged $1.3 \%$ in 1999'. Among the donors were Merck, which donated 'over $\$ 40$ million in cash and over $\$ 100$ million in medicines...' Other donors included Wal-Mart, Kroger, Philip Morris and Procter \& Gamble. Corporate philanthropy is also global in scope. Many corporations engage in philanthropic activities directed at foreign recipients. A number of Fortune 500 companies made donations for disaster relief in the US, Kashmir and South Asia (Muller and Whiteman 2009).

To appreciate the importance of the corporate philanthropy movement, one needs to acknowledge its scope. Corporate philanthropy is not just limited to monetary donations made by corporations. Many corporations encourage philanthropic activities by their employees and customers through various forms of collaboration. Microsoft, Ashland Oil and JPMorgan Chase are among the members of the 'Workplace Giving' campaign, which is 'an employer-sponsored program that offers employees 
the opportunity to make a charitable contribution through payroll deduction' (Global Impact 2009a). The program is coordinated by Global Impact, which 'is a not-for-profit organization dedicated to helping the world's most vulnerable people' (Global Impact 2009b). General Mills Inc. partnered with its customers to raise donations for the Susan G. Komen Breast Cancer Foundation. The company donated 10 cents on behalf of its customers for each pink-top Yoplait yogurt sold (Byrnes 2005). Through a different form of collaboration with its customers, Wal-Mart stores, in certain locations, collected donations for Iowa flood victims of June 2008. Donations were collected in the form of supplies and money. 'The money [was] used to purchase large quantities of items to send' (News Channel 11 2008).

In addition to the broad scope of philanthropic activity, it has been gaining more attention from corporate executives. The CECP reports that the memberships of global CEOs and their attendance of the annual CEO meetings attest to their support of the mission of the CECP: 'to lead the business community in raising the level and quality of corporate philanthropy' (CECP 2009b). This broad scope and attention being received from top executives indicate the extent of the business interest in corporate philanthropy. This interest earned corporate philanthropy a spot on the agenda of CEOs and produced a significant social pressure that mandated a response from corporations.

\section{Business-case arguments for CSR practices}

This section presents business-case arguments for CSR practices. The arguments are organized in four sections corresponding to the four CSR arguments proposed by Kurucz et al. (2008). The first section covers CSR benefits in terms of cost and risk reduction. The second section demonstrates the effects of CSR on competitive advantage. The third section discusses the effects of CSR on company legitimacy and reputation. Finally, the fourth section illustrates the role of CSR in creating win-win situations for the company and society.

Cost and risk reduction. Cost and risk reduction justifications constitute arguments that contend that engaging in certain CSR activities will reduce costs and risks to the firm. '[T] he primary view is that the demands of stakeholders present potential threats to the viability of the organization, and that corporate economic interests are served by mitigating the threats through a threshold level of social or environmental performance' (Kurucz et al. 2008, p. 88).

T. Smith (2005) argues that CSR activities in the form of equal employment opportunity (EEO) policies and practices and environmentally responsible commitments enhance long-term shareholder value by reducing costs and risks. He contends that explicit EEO statements are necessary to illustrate an inclusive policy which reduces employee turnover through improving morale. Smith's argument is consistent with the contentions of others (e.g. Berman et al. 1999; Robinson and Dechant 1997; Thomas and Ely 1996) that '[1]ack of diversity may cause higher turnover and absenteeism from disgruntled employees' (Berman et al. 1999, p. 490).

Cost and risk reduction may also be achieved through CSR activities directed at the natural environment. A number of researchers (e.g. Berman et al. 1999; Dechant et al. 1994; Hart 1995; Shrivastava 1995) contend that being environmentally proactive results in cost and risk reduction. Berman et al. (1999, p. 489) recap: 'being proactive on environmental issues can lower the costs of complying with present and future environmental regulations... [and] ... enhance firm efficiencies and drive down operating costs'. Environmentally responsible commitments may also reduce the negative impact of social concern. For example, '[t]hree separate lawsuits filed in 1999 against 27 well known retailers on behalf of Saipan garment workers demonstrate the business risk associated with inadequate vendor standards' (T. Smith 2005, p. 60).

Corporate social responsibility activities directed at managing community relations may also result in cost and risk reductions (Berman et al. 1999). Building positive community relationships may contribute to the firm's attaining tax advantages. In addition, positive community relationships decrease the amount of regulation imposed on the firm, because the firm is perceived as a sanctioned member of society. Cost and risk reduction arguments for CSR have been gaining wide acceptance among managers and executives. In a survey of business executives by PricewaterhouseCoopers cited in Fortune (2003), $73 \%$ of respondents indicated that 'cost savings' were one of the top three reasons why companies are becoming more socially responsible. Cost savings obviously attract top management attention as a specific bottom-line benefit to CSR.

Gaining competitive advantage. The term 'competitive advantage' in this section is best understood 
in the context of a differentiation strategy. In other words, this section focuses on how firms may use CSR practices to set themselves apart from their competitors. The previous section, which focuses on cost and risk reduction, illustrates how CSR practices may be used to build a competitive advantage through a cost leadership strategy.

Competitive advantage justifications contend that, by engaging in certain CSR activities firms may improve their competitiveness. Stakeholder demands are seen as opportunities rather than constraints. Firms strategically manage their resources to meet these demands and exploit the opportunities associated with them for the benefit of the firm (Kurucz et al. 2008). 'Competitive advantages' was cited as one of the top two justifications for CSR in a survey of business executives reported in Fortune (2003).

N. Smith argues that companies may build their competitive advantage through CSR strategies. He explains: 'a firm's social responsibility strategy, if genuinely and carefully conceived, should be unique ...' N. Smith (2003, p. 67). This uniqueness may serve as a basis for setting the firm apart from its competitors and, accordingly, its competitive advantage. For example, T. Smith (2005) maintains that an explicit statement of EEO policies would have additional benefits to the cost and risk reduction, discussed above. Such policies would provide the firm with a competitive advantage because '[c]ompanies without inclusive policies may be at a competitive disadvantage in recruiting and retaining employees from the widest talent pool' (p. 60).

Corporate social responsibility initiatives can also contribute to strengthening a firm's competitive advantage through enhancing its relationships with its customers. For example, Pivato et al. (2008) demonstrates that CSR initiatives enhance brand loyalty. In another study, Bhattacharya and Sen (2004, p. 10) observe that a "positive link of CSR to consumer patronage is spurring companies to devote greater energies and resources to CSR initiatives'. Corporate social responsibility initiatives were also found to have a positive impact on attracting investment. T. Smith $(2005$, p. 64) reports that many institutional investors 'avoid companies or industries that violate their organizational mission, values, or principles. ... [They also] seek companies with good records on employee relations, environmental stewardship, community involvement, and corporate governance. ...'

The business case for corporate philanthropy may be made when it is justified based on an economic rationale. In other words, corporate philanthropy is substantiated 'if it increases shareholder returns' (Buchholtz et al. 1999, p. 169). Porter and Kramer (2002, p. 59) provide a premise for such an argument. The authors maintain that a business may gain competitive advantages through its philanthropic activities when such activities are directed at causes where there is a 'convergence of interests' between the economic gains and the social benefits.

Bruch and Walter (2005) argue that companies use philanthropy to enhance their competitive advantage through combinations of market (external) and competence (internal) orientations. Through a market orientation, companies design their philanthropic activities to fit external demands and meet the expectations of key stakeholders. The companies therefore improve their competitive advantage through 'improved marketing and selling capabilities, higher attractiveness as an employer or better relationships with governmental and nongovernmental organizations' (Bruch and Walter 2005, p. 50). Deutsche Lufthansa AG, for example, enhances its relationship with communities within which it operates by operating a community-involvement program (Bruch and Walter 2005, p. 50). McDonald's Corporation supports Ronald McDonald House Charities (McDonald's 2009) as its largest corporate donor (Ronald McDonald House Charities 2009).

Through a competence orientation, companies may align their philanthropic activities with their capabilities and core competencies. 'In so doing, they avoid distractions from the core business, enhance the efficiency of their charitable activities and assure unique value creation for the beneficiaries' (Bruch and Walter 2005, p. 50). 'For instance, McKinsey \& Co. offers free consulting services to non-profit organizations in social, cultural and educational fields. Beneficiaries include public art galleries, colleges and charitable institutions' (Bruch and Walter 2005, p. 50). Home Depot Inc. has been providing rebuilding know-how to the communities victimized by Hurricane Katrina (Home Depot 2009). Strategic philanthropy, defined as 'the process by which contributions are targeted to serve direct business interests while also servicing beneficiary organizations' (Tokarski 1999, p. 34), helps companies to gain a competitive advantage and, in turn, boosts its bottom line (Seifert et al. 2003). Corporate philanthropy, in this case, is used as a means of advancing corporate interests.

Corporate social responsibility initiatives enhance a firm's competitive advantage to the extent that they influence the decisions of the firm's stakeholders in 
its favor. Firms build a competitive advantage by engaging in those CSR initiatives that meet 'the perceived demands of stakeholders' (Kurucz et al. 2008, p. 89). In other words, one or multiple stakeholders will prefer the firm over its competitors specifically because of the firm's engagement in such CSR initiatives.

Developing reputation and legitimacy. Reputation and legitimacy arguments maintain that firms may strengthen their legitimacy and enhance their reputation by engaging in CSR activities. Suchman (1995, p. 574) defines legitimacy as 'a generalized perception or assumption that the actions of an entity are desirable, proper, or appropriate within some socially constructed system of norms, values, beliefs, and definitions'. Fombrun and Shanley (1990) explain that perceptions of a firm's concern for society illustrates that the firm is able to build 'mutualistic' relationships, which indicate that the firm is able to operate while adhering to social norms and meeting expectations of different stakeholder groups. Firms 'focus on value creation by leveraging gains in reputation and legitimacy made through aligning stakeholder interests' (Kurucz et al. 2008, p. 90). Reputation and legitimacy sanction the firm to operate in society.

N. Smith contends that CSR activities enhance the ability of a firm to attract consumers, investors and employees. He states that 'consumers report that many claim to be influenced in their purchasing decisions by the CSR reputation of firms' (N. Smith 2003, pp. 61-63). He also reports that '[a]ccording to the Social Investment Forum, \$2.32 trillion or nearly one out of every eight dollars under professional management in the United States was involved in socially responsible investing in 2001' (p. 63). Finally, N. Smith claims that 'some employees express a preference for working for more socially responsible companies' (p. 63). T. Smith presents another example of CSR activities that promote an organization's legitimacy and reputation. T. Smith argues that 'strong vendor standards and independent monitoring' helps build 'a company's reputation and the value of its brand, which are among its most valuable assets' (T. Smith 2005, p. 60).

An example of a CSR activity which is directed at developing reputation and legitimacy is cause marketing. Cause marketing is a strategy where, in addition to emphasizing product advantages, product benefits are linked to appeals for charitable giving (Smith and Alcron 1991). The benefits of this strat- egy include creating purchasing incentives and enhancing company and product images. Through cause marketing, companies are able to illustrate that they can, mutually, pursue their profitability goals and meet the needs of the different stakeholders in society. Therefore they are able to demonstrate that they 'belong' to society. For example, General Mills Inc., through its subsidiary Yoplait USA Inc., donated $\$ 1.5$ million to the breast cancer cause through its Breast Cancer Initiative (Yoplait 2009a). The company donated 10 cents for every 'pink lid' that a consumer sent to the company as proof of purchase of the Yoplait yogurt (Yoplait 2009b). Another example of cause marketing is the buy (RED) initiative. '(RED) is a simple idea that transforms [the] incredible collective power [of] consumers into a financial force to help others in need' (RED 2009). Companies participating in the (RED) initiative donate $50 \%$ of their profits from the product to purchase and distribute antiretroviral medicine to battle AIDS in Africa (RED 2009). Both examples presented above, illustrate how firms are able to underscore that their pursuit of financial gains is not inconsistent with the pursuit of social goals. Rather, the firms are able to illustrate that both goals may be pursued simultaneously. Accordingly, the firms succeed in establishing that their pursuit of financial gains is a legitimate pursuit and is not carried out at the expense of social welfare.

Corporate philanthropy is another CSR activity which aims to enhance corporate legitimacy and reputation. Chen et al. (2008, p. 131) posit that 'corporate philanthropy may ... be a tool of legitimization. ...'The authors argue that some firms that have negative social performance in the areas of environmental issues and product safety use charitable contributions as a means for building their legitimacy. Firms may also use philanthropy to strengthen their legitimacy through managing their local dependency and creating trust (Kamens 1985).

Corporations are also reasoned to enhance their legitimacy and reputation through disclosure of information regarding their performance on different social and environmental issues (Brammer and Pavelin 2004). One such disclosure practice is corporate social reporting. Corporate social reporting refers to the issue of standalone reports that provide information regarding a company's economic, environmental and social performance. The practice of corporate social reporting has been encouraged by the establishment of the GRI in 1997 and the launch of the Global Compact in 1999 (Antal et al. 2002). 
Through the issue of a social report, firms are able to illustrate that their operations are consistent with social norms and expectations, therefore they are legitimate.

Seeking win-win outcomes through synergistic value creation. Synergistic value creation arguments focus on exploiting opportunities that reconcile the differing stakeholder demands. Firms do this by 'connecting stakeholder interests, and creating pluralistic definitions of value for multiple stakeholders simultaneously' (Kurucz et al. 2008, p. 91).

Porter and Kramer (2002, p. 66) argue that, when companies 'get the where and how right', philanthropic activities and competitive advantage become mutually reinforcing and create a virtuous circle. They contend that corporate philanthropy may be used to influence the competitive context of an organization, which would allow the organization to improve its competitiveness and at the same time fulfill the needs of some of its stakeholders. For example, charitable giving to education causes would improve the quality of human resources available for the firm. Similarly, charitable contributions to community cause would result in the creation and preservation of high local quality of life, which may sustain 'sophisticated and demanding local customers' (Porter and Kramer 2002, p. 60).

The notion of creating win-win outcomes through CSR activities has been raised before. Drucker (1984, p. 62) argues 'the proper "social responsibility" of business is to ... turn a social problem into economic opportunity and economic benefit, into productive capacity, into human competence, into well-paid jobs, and into wealth'. Wheeler et al. (2003) echo Drucker's contention. They posit 'it will not be too long before we can begin to assert that the business of business is the creation of sustainable value - economic, social and ecological' (Wheeler et al. 2003, p. 20).

For example, Wheeler et al. contend that the winwin perspective adopted by the life sciences firm Novo Group allowed it to pursue its business '[which] is deeply involved in genetic modification and yet maintains highly interactive and constructive relationships with stakeholders and publishes a highly rated environmental and social report each year' (Wheeler et al. 2003, p. 8). In contrast, Monsanto faced several difficulties in its business, which is of a similar nature to that of Novo Group, due to its neglect of stakeholder demands. Monsanto's difficulties materialized in 'a major backlash (that) occurred in European consumer markets as a result of perceived imposition of unlabelled, genetically modified food, ingredients' (Wheeler et al. 2003, p. 7).

The win-win perspective to CSR practices is aimed at satisfying stakeholders' demands while, at the same time, allowing the firm to pursue its operations. By engaging its stakeholders and satisfying their demands, the firm finds opportunities and solutions which enable it to pursue its profitability interest with the consent and support of its stakeholder environment. The win-win perspective to CSR practices provides a view in which CSR is perceived as a vehicle that allows both the firm to pursue its interest and stakeholders to satisfy their demands.

\section{Limitations of business-case arguments for CSR practices}

While acceptance of the arguments for the business case for CSR has been growing, it is worth noting some of its criticisms and limitations. Valor (2008) argues that consumers may not have the ability to support companies engaging in CSR activities, owing to their limited power in the marketplace. Accordingly, CSR initiatives are not rewarded, and the business case for CSR does not hold. To support CSR initiatives and make the business case for CSR, Valor proposes that policy-makers empower consumers by providing consumers with more information through mandatory reporting on social and environmental performance and the development of a 'comprehensive social or CSR' label (Valor 2008, p. 323).

Another limitation of the business case for CSR is the implied assumption that the positive correlation between carefully chosen CSR initiatives and firm financial performance is perpetual. This implied assumption may not be accurate. Mintzberg (1983) argues that firms may be rewarded, in an economic and financial sense, for engaging in CSR practices to a certain extent. Beyond a given level of CSR investment, the market will cease to reward it. Mintzberg asserts ' $[\mathrm{t}]$ he stock market is willing to reward social responsibility only to a point. It pays to be good but not too good' (Mintzberg 1983, p. 10).

Williamson et al. (2006) found that CSR activities are driven mainly by regulatory structures and the pursuit of direct cost reductions in small and medium-sized manufacturing firms. The authors conclude that the environment in which those firms operate fails to recognize the benefits of the broader business case. In that environment, CSR practices are 
motivated by regulatory compliance and direct causal relationships between CSR and firm financial performance. Similarly to Valor, Williamson et al. appeal for regulation. They assert: 'that regulation has a vital part to play in improving the environmental and social practices of [small and medium sized manufacturing enterprises]' (Williamson et al. 2006, p. 326). De Schutter (2008) has also highlighted the negative effect of what he called 'market failures' and urged for more regulation to support CSR practices.

The criticisms directed at the arguments of the business case for CSR underscore the impact of the market and regulation on CSR practices. As the business case is premised on the notion that the market will reward CSR practices, situations where the market does not support CSR practices strike at the foundation of the business case. Establishing an affirmative answer to the question 'Is there a market for virtue?' (Vogel 2005, p. 19) is therefore essential for making the business case for CSR.

\section{Summary and conclusions}

The business case for CSR refers to the arguments that provide rational justification for CSR initiatives from a primarily corporate economic/financial perspective. Business-case arguments contend that firms which engage in CSR activities will be rewarded by the market in economic and financial terms. A narrow view of the business case justifies CSR initiatives when they produce direct and clear links to firm financial performance. Mostly, the narrow view of the business case focuses on immediate cost savings. By contrast, the broad view of the business case justifies CSR initiatives when they produce direct and indirect links to firm performance. The advantage of the broad view over the narrow view is that it allows the firm to benefit from CSR opportunities. The broad view of the business case for CSR enables the firm to enhance its competitive advantage and create win-win relationships with its stakeholders, in addition to realizing gains from cost and risk reduction and legitimacy and reputation benefits, which are realized through the narrow view.

The broad view enhances the acceptance of the business case for CSR, because it acknowledges the complex and interrelated nature of the relationship between CSR and firm financial performance. Recognizing this complexity translates into a clearer understanding of the impact of CSR initiatives on firm financial performance while accounting for the effects of mediating variables and situational contingencies. The inconsistencies in the results of the responsibility-performance studies may therefore be justified. The benefits of CSR are not homogeneous, and effective CSR initiatives are not generic. Effective CSR rests on developing the appropriate CSR strategy (N. Smith 2003; T. Smith, 2005) where CSR activities are those directed at improving stakeholder relations and, at the same time, improving social welfare (Barnett 2007). The right CSR strategy is the one that pursues issues which demonstrate a convergence between economic and social goals (Porter and Kramer 2006).

To formulate a successful CSR strategy, firms must understand that the benefits of CSR are dependent on mediating variables and situational contingencies. Pivato et al. (2008) illustrate the role of trust as a mediating variable which shapes the relationship between CSR activities and firm performance. Barnett (2007) set out the construct of stakeholder influence capacity, which illustrates how situational contingencies may affect the impact of CSR activities on firm financial performance. It is critical to apply the contingency perspective as suggested by Barnett (2007) and account for the role of mediating variables as proposed by Pivato et al. (2008) in the exploration of the relationship between CSR and firm financial performance. A contingency perspective would allow the development of justifications for the lack of a positive relationship between CSR and firm financial performance in certain circumstances. In addition it would provide a defense for the business case for CSR in environments where the business case is argued to have failed (e.g. De Schutter 2008; Valor 2008; Williamson et al. 2006).

The rationale for the business case for CSR may be categorized under four arguments: (1) reducing cost and risk; (2) strengthening legitimacy and reputation; (3) building competitive advantage; and (4) creating win-win situations through synergistic value creation (Kurucz et al. 2008). Cost and risk reduction arguments posit that CSR may allow a firm to realize tax benefits or avoid strict regulation, which would lower its cost. The firm may also lower the risk of opposition by its stakeholders through CSR activities. Legitimacy and reputation arguments hold that CSR activities may help a firm strengthen its legitimacy and reputation by demonstrating that it can meet the competing needs of its stakeholders and at the same time operate profitably. A firm therefore would be perceived as a member of its community, 
and its operations would be sanctioned. Competitive advantage arguments contend that, by adopting certain CSR activities, a firm may be able to build strong relationships with its stakeholders and garner their support in the form of lower levels of employee turnover, access to a higher talent pool, and customer loyalty. Accordingly, the firm will be able to differentiate itself from its competitors. Synergistic value creation arguments hold that CSR activities may present opportunities for a firm that would allow it to fulfill the needs of its stakeholders and at the same time pursue its profit goals. The pursuit of these opportunities is only possible through CSR activities.

Growing support for the business case among academic and practitioners is evident. Generally, the business case for CSR is being made by documenting and illustrating that CSR has a positive economic impact on firm financial performance. The broad view of the business case, however, brings attention to the details of the relationship between CSR and firm financial performance. Mediating variables and situational contingencies affect the impact of CSR on firm financial performance. Therefore, the impact of CSR on firm financial performance is not always favorable. Rather, firms should understand the circumstances of the different CSR activities and pursue those activities that demonstrate a convergence between the firm's economic objectives and the social objectives of society. Only when firms are able to pursue CSR activities with the support of their stakeholders can there be a market for virtue and a business case for CSR.

\section{References}

Abrams, F.K. (1951). Management's responsibilities in a complex world. Harvard Business Review, XXIX, pp. 29-34.

Ackerman, R. (1973). How companies respond to social demands. Harvard Business Review, July/August, 88-98.

Antal, A.B., Dierkes, M., MacMillan, K. and Martz, L. (2002). Corporate social reporting revisited. Journal of General Management, 28, pp. 22-42.

Barnett, M.L. (2007). Stakeholder influence capacity and the variability of financial returns to corporate social responsibility. Academy of Management Review, 32, pp. 794816.

Berger, I.E., Cunningham, P. and Drumwright, M.E. (2007). Mainstreaming corporate social responsibility: developing markets for virtue. California Management Review, 49, pp. 132-157.

Berman, S.L., Wicks, A.C., Kotha, S. and Jones, T.M. (1999). Does stakeholder orientation matter? The rela- tionship between stakeholder management models and firm financial performance. Academy of Management Journal, 42, pp. 486-506.

Bernstein, A. (2000). Too much corporate power. Business Week, 11 September, p. 149.

Bhattacharya, C.B. and Sen, S. (2004). Doing better at doing good: when. why, and how consumers respond to corporate social initiatives. California Management Review, 47, pp. 9-24.

Bowen, H. (1953). Social Responsibilities of the Businessman. New York: Harper.

Brammer, S. and Pavelin, S. (2004). Voluntary social disclosure by large UK companies. Business Ethics: A European Review, 13(2/3), 86-99.

Bruch, H. and Walter, F. (2005). The keys to rethinking corporate philanthropy. MIT Sloan Management Review, 47, pp. 48-56.

Buchholtz, A.K., Amason, A.C. and Rutherford, M.A. (1999). Beyond resources: the mediating effect of top management discretion and values on corporate philanthropy. Business and Society, 38, pp. 167-187.

BusinessGreen (2008). U.S. Execs: CSR initiatives do boost the bottom line. Available at: http://BusinessGreen.com (accessed 4 December 2008).

Byrnes, N. (2005). Smarter corporate giving. Business Week, 28 November, 68-76.

Carroll, A.B. (1979). A three-dimensional conceptual model of corporate social performance. Academy of Management Review, 4, pp. 497-505.

Carroll, A.B. (1991). The pyramid of corporate social responsibility: toward the moral management of organizational stakeholders. Business Horizons, July-August, pp. 39-48.

Carroll, A.B. (1999). Corporate social responsibility: evolution of a definitional construct. Business and Society, 38, pp. 268-295.

Carroll, A.B. (2008). A history of corporate social responsibility: concepts and practices. In Crane, A., McWilliams, A., Matten, D., Moon, J. and Siegel, D. (eds), The Oxford Handbook of Corporate Social Responsibility. Oxford: Oxford University Press, pp. 19-46.

Carroll, A.B. (2009). A look at the future of business ethics. Athens Banner-Herald, 10 January.

Carroll, A.B. and Buchholtz, A.K. (2009). Business and Society: Ethics and Stakeholder Management, 7th edn. Mason, OH: South-Western Cengage Learning.

Chen, J.C., Patten, D.M. and Roberts, R. (2008). Corporate charitable contributions: a corporate social performance or legitimacy strategy? Journal of Business Ethics, 82, pp. 131-144.

Committee Encouraging Corporate Philanthropy (2009a). Giving in Numbers: 2008 Edition. New York: Committee Encouraging Corporate Philanthropy.

Committee Encouraging Corporate Philanthropy (2009b). CEO conference. Available at: http://www.corporate philanthropy.org/index.php?option=com_content\&view= article\&id=70\&Itemid=147 (accessed 20 March 2009). 
Cray, C. (2000). A sweeter cup. Multinational Monitor, May, p. 4.

Dahlsrud, A. (2006). How corporate social responsibility is defined: an analysis of 37 definitions. Corporate Social Responsibility and Environmental Management, September. Available at: http://www.csr-norway.no/papers/ 2007_dahlsrud_CSR.pdf

Davis, K. (1960). Can business afford to ignore social responsibilities? California Management Review, $\mathbf{2}$, pp. 70-76.

Davis, K. (1973). The case for and against business assumption of social responsibilities. Academy of Management Journal, June, pp. 312-322.

De Schutter, O. (2008). Corporate social responsibility European style. European Law Journal, 14, pp. 203236.

Dechant, K., Altman, B., Downing, R.M. and Keeney, T. (1994). Environmental leadership: from compliance to competitive advantage. Academy of Management Executive, 8, pp. 7-28.

Drucker, P.F. (1954/2006). The Practice of Management. New York: Collins.

Drucker, P.F. (1984). The new meaning of corporate social responsibility. California Management Review, 26, pp. 53-63.

Fombrun, C. and Shanley, M. (1990). What's a name? Reputation building and corporate strategy. Academy of Management Review, 33, 233-258.

Fortune (2003). Corporate America's social conscience, 26 May, S8.

Frederick, W.C. (1960). The growing concern over social responsibility. California Management Review, 2, pp. 54-61.

Frederick, W.C. (1978). From CSR1 to CSR2: the maturing of business and society thought. Working Paper 279, Graduate School of Business, University of Pittsburgh.

Frederick, W.C. (2006). Corporation, Be Good! The Story of Corporate Social Responsibility. Indianapolis, IN: Dogear Publishing.

Frederick, W.C. (2008). Corporate social responsibility: deep roots, flourishing growth, promising future. In Crane, A., McWilliams, A., Matten, D., Moon, J. and Siegel, D. (eds), The Oxford Handbook of Corporate Social Responsibility. Oxford: Oxford University Press, pp. 522-531.

Friedman, M. (1962). The social responsibility of business is to increase its profits. New York Times, September, 126.

Global Impact (2009a). Workplace giving. Available at: http://www.charity.org/site/c.gtJUJfMQIqE/b.3416753/ k.99D0/Workplace_Giving.htm. (accessed 22 March 2009).

Global Impact (2009b). About global impact. Available at: http://www.charity.org/About_Us. (accessed 5 July 2009).

Global Reporting Initiative (2006). Sustainability Reporting Guidelines. Amsterdam: Global Reporting Initiative.
Griffin, J.J. and Mahon, J.F. (1997). The corporate social performance and corporate financial performance debate. Business \& Society, 36, p. 5.

Hart, S. (1995). A natural-resource-based view of the firm. Academy of Management Review, 20, pp. 986-1014.

Hay, R. and Gray, E. (1974). Social responsibilities of business managers. Academy of Management Journal, March, pp. 135-143.

Hayek, F.A. (1969). The corporation in a democratic society: in whose interest ought it and will it be run? In Ansoff, $\mathrm{H}$. (ed.), Business Strategy. Harmondsworth: Penguin Books, p. 225.

Home Depot (2009). Rebuilding hope and homes: mapping our impact. Available at: http://rhh.homedepot.com/ pc.htm (accessed 23March 2009).

Jackson, K.T. (2004). Building Reputational Capital: Strategies for Integrity and Fair Play that Improve the Bottom Line. Oxford: Oxford University Press.

Kamens, D.H. (1985). A theory of corporate civic giving. Sociological Perspectives, 28, pp. 29-49.

KLD Research and Analytics, Inc. (2009). Socrates ratings indicators. Available at: http:/www.kld.com/research/ socrates/indicators.html (accessed 18March 2009).

Kotler, P. and Lee, N. (2005). Corporate Social Responsibility: Doing the Most Good for Your Company and Your Cause. Hoboken, NJ: Wiley.

Kurucz, E., Colbert, B. and Wheeler, D. (2008). The business case for corporate social responsibility. In Crane, A., McWilliams, A., Matten, D., Moon, J. and Siegel, D. (eds), The Oxford Handbook of Corporate Social Responsibility. Oxford: Oxford University Press, pp. 83-112.

Laszlo, C. (2003). The Sustainable Company: How to Create Lasting Value through Social and Environmental Performance. Washington: Island Press.

Lee, M.P. (2008). A review of the theories of corporate social responsibility: its evolutionary path and the road ahead. International Journal of Management Reviews, 10, pp. 53-73.

Levitt, T. (1958). The dangers of social responsibility. Harvard Business Review, September-October, pp. 41-50.

Mahon, J.F. and Griffin, J.J. (1999). Painting a portrait: a reply. Business and Society, 38, pp. 126-133.

Margolis, J.D. and Walsh, J.P. (2003). Misery loves companies: social initiatives by business. Administrative Science Quarterly, 48, pp. 268-305.

McDonald's (2009). Values in practice. Available at: http:// www.crmcdonalds.com/publish/csr/home/about/ community.html (accessed 23 March 2009).

McGuire, J. (1963). Business and Society. New York: McGraw-Hill.

Mintzberg, H. (1983). The case for corporate social responsibility. Journal of Business Strategy, 4, pp. 3-15.

Moon, J. (2005). An explicit model of business-society relations. In Habisch, A., Jonker, J., Wegner, M. and Schmid- 
peter, R. (eds), Corporate Social Responsibility Across Europe. Berlin: Springer, pp. 51-65.

Muller, A. and Whiteman, G. (2009). Exploring the geography of corporate philanthropic disaster response: a study of Fortune Global 500 firms. Journal of Business Ethics, 84, pp. 589-603.

Murphy, P.E. (1978). An evolution: corporate social responsiveness. University of Michigan Business Review, November, pp. 20-22.

Murray, E.A., Jr (1976). The social response process in commercial banks: an empirical investigation. Academy of Management Review, July.

News Channel 11 (2008). Area Wal-Mart stores collecting donations for Iowa flood victims. Available at: http:// www.tricities.com/tri/news/local/article/area_walmart_ stores_collecting_donations_for_iowa_flood_victims/ 11064/. (accessed on 22 March 2009).

O'Sullivan, K. (2006). Virtue rewarded: companies are suddenly discovering the profit potential of social responsibility. CFO, October, pp. 47-52.

Orlitzy, M., Schmidt, F.L. and Rynes, S.L. (2003). Corporate social and financial performance: a meta-analysis. Organization Studies, 24, pp. 403-441.

Phillips, R.R., Freeman, R.E. and Wicks, A.C. (2003). What stakeholder theory is not. Business Ethics Quarterly, 13, pp. 479-502.

Pivato, S., Misani, N. and Tencati, A. (2008). The impact of corporate social responsibility on consumer trust: the case of organic food. Business Ethics: A European Review, 17, pp. 3-12.

Porter, M.E. and Kramer, M.R. (2002). The competitive advantage of corporate philanthropy. Harvard Business Review, 80, pp. 56-69.

Porter, M.E. and Kramer, M.R. (2006). Strategy \& society: the link between competitive advantage and corporate social responsibility. Harvard Business Review, 84, pp. 78-92.

Printing World (2005). Antalis outlines green stance. Printing World, 289, pp. 41-41.

RED (2009). The (RED) idea. Available at: http:// www.joinred.com/Learn/AboutRed/Idea.aspx (accessed 4 May 2009).

Robinson, G. and Dechant, K. (1997). Building a business case for diversity. Academy of Management Executive, 11, pp. 21-31.

Roman, R.M., Hayibor, S. and Agle, B.R. (1999). The relationship between social and financial performance. Business \& Society, 38, p. 109.

Ronald McDonald House Charities (2009). Our relationship with McDonald's. Available at: http://www.rmhc.org/ who-we-are/our-relationship-with-mcdonald-s/ (accessed 23 March 2009).

Schwartz, M. and Carroll, A.B. (2008). Integrating and unifying competing and complimentary frameworks: the search for a common core in the business and society field. Business and Society, 47, pp. 148-186.
Scott, M. and Rothman, H. (1992). Companies with a Conscience: Intimate Portraits of Twelve Firms that Make a Difference. New York: Citadel.

Seifert, B., Morris, S.A. and Bartkus, B.R. (2003). Comparing big givers and small givers: financial correlates of corporate philanthropy. Journal of Business Ethics, 45, pp. 195-211.

Seifert, B., Morris, S.A. and Bartkus, B.R. (2004). Having, giving, and getting: slack resources, corporate philanthropy, and firm financial performance. Business and Society, 43, pp. 135-161.

Sethi, S.P. (1975). Dimensions of corporate social performance: an analytic framework. California Management Review, Spring, pp. 58-64.

Shrivastava, P. (1995). The role of corporations in achieving ecological sustainability. Academy of Management Review, 20, pp. 936-960.

Smith, N.C. (2003). Corporate social responsibility: whether or how? California Management Review, 45, pp. 52-76.

Smith, S.M. and Alcron, D.S. (1991). Cause marketing: a new direction in the marketing of corporate responsibility. Journal of Consumer Marketing, 8, pp. 19-35.

Smith, T. (2005). Institutional and social investors find common ground. Journal of Investing, 14, pp. 57-65.

Spector, B. (2008). Business responsibilities in a divided world: the cold war roots of the corporate social responsibility movement. Enterprise \& Society, 9, pp. 314-336.

Starbucks (2009). Starbucks, Transfair USA and Fairtrade labeling organizations international announce groundbreaking initiative to support small-scale coffee farmers. Available at: http://www.starbucks.com/aboutus/ pressdesc.asp?id=929 (accessed 18 March 2009).

Suchman, M.C. (1995). Managing legitimacy: strategic and institutional approaches. Academy of Management Journal, 20, pp. 571-610.

Thomas, D. and Ely, R. (1996). Making differences matter: a new paradigm for managing diversity. Harvard Business Review, 74, pp. 79-90.

Tokarski, K. (1999). Give and thou shall receive. Public Relations Quarterly, 44, pp. 34-40.

Valor, C. (2008). Can consumers buy responsibly? Analysis and solutions for market failures. Journal of Consumer Policy, 31, pp. 315-326.

Vogel, D.J. (2005). Is there a market for virtue? The business case for corporate social responsibility. California Management Review, 47, pp. 19-45.

Waddock, S. (2002). Leading Corporate Citizens: Vision, Values, Value-added. New York: McGraw-Hill.

Wartick, S.L. and Cochran, P.L. (1985). The evolution of the corporate social performance model. Academy of Management Review, 10, pp. 765-766.

Wheeler, C., Colbert, B. and Freeman, R.E. (2003). Focusing on value: reconciling corporate social responsibility, sustainability and a stakeholder approach in a network world. Journal of General Management, 28(3), pp. 128. 
Williamson, D., Lynch-Wood, G. and Ramsay, J. (2006). Drivers of environmental behaviour in manufacturing SMEs and the implications for CSR. Journal of Business Ethics, 67, pp. 317-330.

Wood, D.J. (1991). Corporate social performance revisited. Academy of Management Review, October, pp. 691-718.

Yoplait (2009a). You did it! Available at: http://www. yoplait.com/slsl/ (accessed 4 May 2009).
Yoplait (2009b). Commitment. Available at: http:// www.yoplait.com/sls1/HowItWorks.aspx (accessed 4 May 2009).

Zadek, S. (2000). Doing Good and Doing Well: Making the Business Case for Corporate Citizenship. Research Report 1282-00-RR. New York: The Conference Board. 